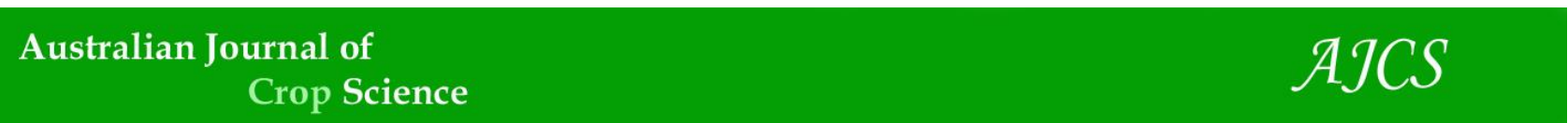

AJCS 15(06):882-889 (2021)

ISSN:1835-2707

doi: 10.21475/ajcs.21.15.06.p3034

\title{
Composition and Antimicrobial Activity of Ginger (Zingiber officinalle Roscoe)
}

\author{
Amandha Lara ${ }^{1}$, Isabela Carvalho dos Santos ${ }^{2}$, Andréia Assunção Soares ${ }^{1,2}$, Luciana Kazue Otutumi ${ }^{2}$, Ezilda \\ Jacomassi ${ }^{1}$, Evellyn Claudia Wietzikoski Lovato ${ }^{1}$, Zilda Cristiani Gazim ${ }^{3}$, Isabelle Luiz Rahal ${ }^{3}$, Leiluana \\ Roque Oliva ${ }^{4}$, José Eduardo Gonçalves ${ }^{4}$, Lidiane Nunes Barbosa ${ }^{2}$, Daniela Dib Gonçalves ${ }^{1,2^{*}}$ \\ ${ }^{1}$ Mestrado Profissional de Plantas Medicinais e Fitoterápicos na Atenção Básica, Universidade Paranaense \\ (UNIPAR), Umuarama, Paraná, Brasil. Praça Mascarenhas de Moraes, 4282 - Centro - CEP: 87502-210, Umuarama - \\ Paraná, Brasil \\ ${ }^{2}$ Programa de Pós-Graduação em Ciência Animal com Ênfase em Produtos Bioativos, da Universidade Paranaense \\ (UNIPAR), Umuarama, Paraná, Brasil. Praça Mascarenhas de Moraes, 4282 - Centro - CEP: 87502-210, Umuarama - \\ Paraná, Brasil \\ ${ }^{3}$ Programa de Pós-graduação em Biotecnologia Aplicada a Agricultura, Laboratório de Química de Produtos \\ Naturais, Universidade Paranaense, Umuarama, PR, Brasil. Praça Mascarenhas de Moraes, 4282 - Centro - CEP: \\ 87502-210, Umuarama - Paraná, Brasil \\ ${ }^{4}$ Programa de Pós-graduação em Tecnologias Limpas, Centro Universitário de Maringá, Maringá, Paraná, Brasil. Av. \\ Guedner, no 1610 - Jardim Aclimação, Maringá Paraná, Brasil
}

\section{*Corresponding author: danieladib@prof.unipar.br}

\section{Abstract}

Zingiber officinale Roscoe has been widely used for hundreds of years, whether for its analgesic, antipyretic, or antimicrobial potential. The aim of this study was to evaluate the composition and the ranges of minimum inhibitory concentration (MIC) and minimum bactericidal concentration (MBC) of aqueous rhizome and leaf extracts of $Z$. officinale and synergism of these extracts with antibiotics against six isolates of Staphylococcus spp. The chemical composition of the crude extract from the rhizome of $Z$. officinale cultivated in the region of Umuarama (Brazil) was analyzed by gas chromatography coupled with a mass spectrometer and detected Zingerone (47.65\%), $\alpha$-Zingiberene (14.92\%), $\beta$-Sesquiphellandrene- (6.16\%), $\alpha$-Curcumene (4.49\%), Methyl 10-trans, 12-cis-octadecadienoate (4.42) and Gingerol (4.37). Six samples of Staphylococcus spp. from Veterinary Students' nasal swabs were collected for antimicrobial susceptibility tests. The antibacterial activities of the aqueous extracts of ginger rhizome and leaves were evaluated with broth microdilution, and then synergism of the rhizome extract with the antimicrobials was verified to calculate the fractional inhibitory concentration index (FICl). All the Staphylococcus spp. samples showed resistance to ampicillin and penicillin, $66.67 \%$ to erythromycin, and $33.33 \%$ to tetracycline. The $\mathrm{MIC}_{90 \%}$ of each extract was estimated to be $235 \mathrm{mg} / \mathrm{mL}$ and $13.27 \mathrm{mg} / \mathrm{mL}$ for the leaf and rhizome, respectively. With the aqueous leaf extract, none of the samples presented MBC within the studied concentration range. On the other hand, the $\mathrm{MBC}$ obtained by the aqueous rhizome extract was $7.81 \mathrm{mg} / \mathrm{mL}$ for $50 \%$ of the samples. Calculation of the $\mathrm{FICl}$ showed that $1 / 2$ MIC yielded the best result, with two synergistic relationships when combined with ampicillin. This research shows a potential use for the aqueous extract of ginger as an alternative or auxiliary therapy against resistant microorganisms.

Keywords: Aqueous extract; E-test; Ginger; Staphylococcus.

Abbreviations: FICl_Fractional Inhibitory Concentration Index, MBC_Minimum Bactericidal Concentration, MIC_Minimum Inhibitory Concentration.

\section{Introduction}

Humans, animals, and plants are large reservoirs of bacteria, which are found lining the skin, mucous membranes, and surface of the gastrointestinal tract in men and animals (Rajapaksha et al., 2019). The Staphylococcus spp. is one of the most commonly encountered bacteria in clinical practice as it colonizes the skin of up to $15 \%$ of humans and is easily found in the nasal cavities, besides causing infectious diseases ranging from a simple infection (pimples, boils, and cellulitis) to serious infections such as pneumonia, meningitis, endocarditis, toxic shock syndrome, and septicemia (Becker et al., 2014; Saber et al., 2017). This microorganism can also be found in animals, whether production or pet, there are also reports in the literature of their transmission between animals and humans (Kuroda et al., 2016; Van Duijkeren et al., 2011).

From 1950, when antibiotics became widely used, the phenomenon of bacterial resistance began. Since then, the problem of resistance to antibiotics has come to represent considerable importance in public health (Singer et al., 2016) and a major global problem (WHO, 2018).

The misuse of antimicrobials, the wrong prescription by the health professional, the non-compliance with the stipulated 
therapeutic doses, the abandonment of treatment, among other causes, are cited in the literature as causing bacterial resistance; and it is known that staphylococcal infections are no longer confined to intensive care units, acute care hospitals or any health institution (ANVISA, 2004).

According to WHO (2018) currently, the main public health problem in the world is antimicrobial resistance, and it is caused by the misuse of antimicrobials, faulty prescriptions by health professionals, non-compliance with the prescribed therapeutic doses, and abandonment of the treatment, among others. Additionally, staphylococcus infections are no longer confined to intensive care units, acute care hospitals, or any healthcare facility (ANVISA, 2008).

Medicinal plants are spread all over the world, and they are known to be a rich source of molecules that can therapeutically be exploited. They can be classified according to their medical values: those directly used in therapy, followed by those that constitute the raw material for compounding, and, lastly, those used in the industry to obtain bioactive ingredients or as precursors in semi syntheses (Hasenclever et al., 2017).

Standing out because of its bioactive compounds, the Zingiberaceae family has long been used in diets as seasonings in addition to the pharmaceutical and cosmetic industries as antioxidant and antimicrobial agents. The bioactive compounds of this plant family are of fundamental importance for maintaining "One Health" and can prevent or ameliorate various types of diseases (Chan and Wong, 2015; Soares et al., 2018).

The Zingiber officinale Roscoe, popularly known as ginger, is an aromatic plant used by Asians as a condiment and medicinal herb since ancient times. It has been distributed across the continents via spice trade and during the Age of Discovery. It is currently marketed fresh, preserved, crystallized, dried, or powdered (Soares et al., 2018). The ginger rhizome has a slightly flat, elongated body with irregularly fragmented branches, which are 3-16 cm long, 3$4 \mathrm{~cm}$ wide, and $2 \mathrm{~cm}$ thick. Externally, its coloration ranges from yellow leather to bright brown; it is longitudinally striated, sometimes fibrous, and has endings that obliquely arise from the rhizomes. The endings, also known as "fingers", are flat, obovate, and short extensions of $1-3 \mathrm{~cm}$ in length. Starch is the main constituent of the cortex and central cylinder. Internally, it has a yellowish-brown color with fibrovascular bundles scattered over the entire surface. Additionally, there are numerous gray spots and oleoresin cells with yellow contents; a yellow endodermis separates the narrow cortex from the broad stele (Soares et al., 2018). The rhizome is the most exploited part of the plant. The essential oil of rhizomes is used in the food industry as a flavoring oil and condiment; in the cosmetic industry, it is used as a fragrance and antioxidant, and in the pharmaceutical industry, as an anti-inflammatory, -bacterial, and -tumor agent (Shahrajabian et al., 2019). Tea-making is another very popular use of this part of ginger, and ginger tea is known for its antimicrobial, analgesic, and antiinflammatory potential, among other benefits (Shahrajabian et al., 2019).

Gingers are recognized as safe by the American Food and Drug Administration (FDA) and have no side effects when consumed in moderate amounts (Azizi et al., 2015). Research shows that in addition to rhizomes, the leaves and flowers of some ginger species have medicinal potential (Chan et al., 2011; Soares et al., 2018).
The aim of this study was to evaluate the composition and the antimicrobial activity using the minimum inhibitory/bactericidal concentrations (MICs/MBCs) of aqueous extracts of Zingiber officinale Roscoe as well as the synergistic potential of these extracts with antimicrobials against a standard strain and isolates of Staphylococcus spp.

\section{Results}

\section{Disk Diffusion Test}

According to the disk diffusion test (Table 1), all the samples $(100 \%)$ showed resistance to ampicillin and penicillin, four (66.67\%) were resistant to erythromycin, two (33.33\%) were resistant to tetracycline, and one (16.67\%) was resistant to gentamicin. However, none of the samples showed resistance to cephalothin, clindamycin, cefotaxime, enrofloxacin, oxacillin, or vancomycin (Table 2).

\section{Extract analysis by gas chromatography and mass spectroscopy}

The chemical composition of the crude extract extracted from the rhizomes of $Z$. officinale cultivated in the region of Umuarama (Paraná-Brazil) was analyzed by gas chromatography coupled to a mass spectrometer (GC-MS). In total, 17 compounds were identified, representing $97.45 \%$ of the sample's volatile components (Table 3). The major substances identified were Zingerone (47.65\%), $\alpha$ Zingiberene (14.92\%), $\beta$-Sesquiphellandrene- (6.16\%), $\alpha$ Curcumene (4.49\%), Methyl 10-trans, 12 -cisoctadecadienoate (4.42), and Gingerol (4.37).

\section{Evaluation of the antibacterial activity of the extract}

Among the Staphylococcus spp. Samples tested against the aqueous extracts of Zingiber officinale Roscoe leaves, five (83.33\%) exhibited MIC of $250 \mathrm{mg} / \mathrm{mL}$, and one (16.67\%) had a MIC equal to $125 \mathrm{mg} / \mathrm{mL}$, but none of the six samples presented $M B C$ within the concentration range studied (Table 4).

The results obtained by the aqueous extract of the Zingiber officinale Roscoe rhizome were lower, in which four $(66.67 \%)$ of the samples presented a MIC equal to 7.81 $\mathrm{mg} / \mathrm{mL}$, and two (33.33\%) samples presented $15.62 \mathrm{mg} / \mathrm{mL}$. As for the MBC, three $(50.00 \%)$ samples yielded $7.81 \mathrm{mg} / \mathrm{mL}$, two (33.33\%) samples had the values of $15.62 \mathrm{mg} / \mathrm{mL}$ and $31.25 \mathrm{mg} / \mathrm{mL}$, and another sample's MBC was not lower than $250 \mathrm{mg} / \mathrm{mL}$ (Table 5).

The $\mathrm{MIC}_{90 \%}$ of each extract was calculated, and the values obtained were $235 \mathrm{mg} / \mathrm{mL}$ and $13.27 \mathrm{mg} / \mathrm{mL}$ for leaf and rhizome, respectively.

\section{Verification of the synergism between the aqueous extract} of $Z$. officinale rhizome and conventional antimicrobials

The samples were classified according to the E-test using the $\mathrm{FICl}$ calculation, whereby two synergistic relationships and two additives were obtained from the ratio of $1 / 2$ of the extract's MIC with ampicillin, whereas there was one synergistic and two additive relationships with oxacillin, and there were three additive relationships with vancomycin (Table 6).

Regarding the results for the tests using $1 / 4$ MIC in combination with ampicillin, there were two synergistic and two additive relationships, while the combination with oxacillin had four additive relationships, and the combination with vancomycin had one additive relationship (Table 7). 


\section{Discussion}

The antimicrobial resistance is a problem involving One Health and tackling this problem is of worldwide interest. Antimicrobial resistance can naturally be caused by environmental selective pressure, presence of resistance genes, self-medication, or faulty prescription of antimicrobials by health professionals (WHO, 2018; Moraes et al., 2016; Tavares, 2000).

Popularly ginger tea made from chunks of the freshly boiled rhizome is used to treat colds, coughs, and colds as it is used in juices and salads. Ginger leaf tea also has good results for antibacterial action, but the concentration of phenolic compounds in rhizome aqueous extract is higher than those found in leaves according to the literature. This study used the aqueous extract of ginger in order to get as close as possible to its popular use, which is in the form of teas, and thus verify its effectiveness as a possible inhibitor of microorganisms as well as the hydroalcoholic extract of the same plant (Shahrajabian et al., 2019; Azizi et al., 2015).

Among the isolates tested, $100 \%$ (six) were resistant to two of the $\beta$-lactams tested- ampicillin and penicillin. Penicillin resistance was first described in 1944, a few years after its discovery, and it is today well known that Staphylococcus spp. are resistant to penicillin and ampicillin, explaining the prevalence of resistance to these antimicrobials among the isolates evaluated in the present study. However, these same isolates were not found resistant to oxacillin and cephalothin, showing that these two antimicrobials of the same class can be used against infections caused by such bacteria (Tavares, 2000).

The high prevalence of penicillin resistance was also observed by Coelho et al. (2007) among the Staphylococcus spp. samples he evaluated. He observed that $80.9 \%$ of the samples were resistant to ampicillin and penicillin, but $100 \%$ of these samples were resistant to oxacillin, contrary to what was found in the present study.

One sample (16.66\%) was found resistant to gentamicin in this study. This observation also differs from those of Coelho et al. (2007), who observed that $52.3 \%$ of human isolates of Staphylococcus spp. were gentamicin-resistant.

Two samples (33.33\%) were resistant to tetracycline, a result similar to that found by Lozano et al. (2017), where, in their research with humans who had contact with dogs, $75 \%$ of their samples were tetracycline resistant. This result demonstrates a possible transmission of microorganisms and their resistance between both species as already stated by Van Duijkeren et al. (2011).

Menegotto and Picoli (2007) observed 45\% erythromycinresistance among the 40 isolates they studied. This observation is similar to the results of the present study, in which $66.66 \%$ of the samples were resistant to erythromycin. Argudín et al. (2015) also observed a high prevalence of erythromycin-resistance, with $43 \%$ of the samples showing resistance. Even though erythromycinresistance was found in human Staphylococcus spp. isolates, there are no records showing that this resistance is as prevalent as that observed among the isolates found in animal samples. Argudin et al. (2015), raising the possibility of a microorganism sharing between animals and man.

Although there are several studies that showed a high frequency of bacterial resistance (Coelho et al., 2007;
Argudin et al., 2015), in this study, two of six (33.33\%) samples are considered multi-resistant. This result reveals the worrisome selection microorganisms have undergone in many ways, besides highlighting the presence of multiresistance in isolates from apparently healthy individuals.

The problem of antimicrobial resistance is of worldwide interest, and the search for new drugs, changes in the strategy to fight these microorganisms, and also the search for medicinal plants that have antimicrobial properties are fundamental for the establishment of alternative therapies with high expectations of success (WHO, 2018; Moraes et al., 2016; Tavares, 2000).

The major compound was found in the extract used for this study, zingerone is a product of the heating of gingerols, and its high presence can be explained by the form of extraction used in this study, in addition to elucidating the antibacterial effects found that may be caused by the presence of gingerols (Azizi et al., 2015; Jardim et al., 2019). Azizi et al. (2015), in his study, found a MIC of $0.02 \mathrm{mg} / \mathrm{mL}$ of the ethanolic extract of $Z$. officinale compared to isolates of Streptococcus mutans, a lower result than the present study, such concentration can be explained by the chosen form of extraction, because the ethanolic extraction tends to release more phenolic opposites than aqueous.

Sebiomo et al. (2011) found in their work, using the ginger rhizome, a MIC of $200 \mathrm{mg} / \mathrm{mL}$ against an isolate of Staphylococcus aureus, which is a value similar to the one found in the present study, considering that the $\mathrm{MIC}_{90}$ of these samples was $235 \mathrm{mg} / \mathrm{mL}$. However, another factor that should be noted is the bacterial resistance in the tested microorganisms, which showed an average of three antimicrobial resistances per isolate. Saad et al. (2014) obtained a MIC equal to $100 \mathrm{mg} / \mathrm{mL}$, a value that is lower than the one found in this study, but the tested sample did not show multiresistance either, or the presence of a resistance-conferring gene.

The need for a high concentration of ginger leaf aqueous extract to obtain an antimicrobial activity may be linked to the phytochemical characteristics of the leaves as previously reported. Therefore, for medicinal use, the priority should be given to the parts of the plant that comprise the components with antimicrobial properties (Chand, 2019).

Sebiomo et al. (2011) also verified the MIC of the aqueous extract of ginger rhizome, obtaining a MIC value of 200 $\mathrm{mg} / \mathrm{mL}$. Likewise, Saad et al. (2014) obtained a MIC of 100 $\mathrm{mg} / \mathrm{mL}$. Both these values are higher than the one found in the present study, which obtained a $\mathrm{MIC}_{90}$ of $13.27 \mathrm{mg} / \mathrm{mL}$. This discrepancy may be due to the amount of the phenolic components that may be present in the extracts used in the different studies. However, studies performed with the aqueous extract of this plant are lacking, and thus further studies should be performed to find the action mechanism of this plant against microorganisms.

Many studies have shown that ginger bioactive compounds can be an excellent antimicrobial against several pathogens, especially for Gram-negative and Gram-positive bacteria (Soares et al., 2018; Voravuthikunchai, 2007; Suhad, 2012). Infectious diseases represent a major cause of morbidity and mortality in the general population. Pharmaceutical companies have been motivated to develop new 
Table 1. Resistance profiles of Staphylococcus spp. negative coagulase isolated from six nasal swabs from veterinary students at the University of Paraná (UNIPAR), Paraná, Brazil, 2018.

\begin{tabular}{|c|c|c|c|c|c|c|c|c|c|c|c|}
\hline & \multicolumn{11}{|c|}{ Antibiotics and Resistance } \\
\hline & AMP & CFL & $\mathrm{CLI}$ & CTX & ENO & ERI & GEN & OXA & PEN & TET & VAN \\
\hline 1 & $\mathrm{R}$ & S & $\mathrm{S}$ & S & S & $\mathrm{R}$ & S & S & $\mathrm{R}$ & $\mathrm{R}$ & $S$ \\
\hline 2 & $\mathrm{R}$ & S & $\mathrm{S}$ & $S$ & $S$ & $\mathrm{R}$ & $S$ & $S$ & $\mathrm{R}$ & $S$ & S \\
\hline 3 & $\mathrm{R}$ & S & S & S & S & $\mathrm{R}$ & $S$ & $S$ & $\mathrm{R}$ & $\mathrm{R}$ & S \\
\hline 4 & $\mathrm{R}$ & $\mathrm{S}$ & $S$ & S & $S$ & 1 & $\mathrm{~S}$ & $\mathrm{~S}$ & $\mathrm{R}$ & $S$ & $S$ \\
\hline 5 & $\mathrm{R}$ & S & $\mathrm{S}$ & S & S & $\mathrm{S}$ & $\mathrm{R}$ & $S$ & $\mathrm{R}$ & $\mathrm{S}$ & $S$ \\
\hline 6 & $\mathrm{R}$ & $S$ & $S$ & $S$ & $S$ & $\mathrm{R}$ & $S$ & $S$ & $\mathrm{R}$ & $S$ & $S$ \\
\hline
\end{tabular}

Legend: AMP - Ampicillin, CFL - Cephalothin, CLI - Clindamycin, CTX - Cefotaxime, ENO - Enrofloxacin, ERI - Erythromycin, GEN - Gentamicin, OXA - Oxacillin, PEN - Penicillin, TET - Tetracycline, VAN Vancomycin, R - Resistant, S - Sensitive, I- Intermediate.

Table 2. Resistance profiles and multiresistance indexes of the antibiotics used against the Staphylococcus spp. negative coagulase isolated from six nasal swabs from veterinary students at the University of Paraná (UNIPAR), Paraná, Brazil, 2018.

\begin{tabular}{|c|c|c|c|}
\hline \multicolumn{4}{|c|}{ Bacterial Resistance } \\
\hline \multirow[t]{2}{*}{ Antibiotics } & & & Multiresistance Index \\
\hline & $\mathrm{R}$ & $\%$ & \\
\hline \multirow{6}{*}{$\begin{array}{l}\text { Ampicillin } \\
\text { Cephalothin } \\
\text { Clindamycin } \\
\text { Cefotaxime } \\
\text { Enrofloxacin } \\
\text { Erythromycin }\end{array}$} & 06 & 100 & 1 \\
\hline & 0 & 0 & 0 \\
\hline & 0 & 0 & 0 \\
\hline & 0 & 0 & 0 \\
\hline & 0 & 0 & 0 \\
\hline & 04 & 66.67 & 0.667 \\
\hline \multirow{5}{*}{$\begin{array}{l}\text { Gentamicin } \\
\text { Oxacillin } \\
\text { Penicillin } \\
\text { Tetracycline } \\
\text { Vancomycin }\end{array}$} & 01 & 16.67 & 0.167 \\
\hline & 0 & 0 & 0 \\
\hline & 06 & 100 & 1 \\
\hline & 02 & 33.33 & 0.333 \\
\hline & 0 & 0 & 0 \\
\hline
\end{tabular}

Table 3. Chemical composition of the crude extract extracted from the rhizomes of $Z$. officinale cultivated in the region of Umuarama), Paraná, Brazil, 2018.

\begin{tabular}{|c|c|c|c|c|c|c|}
\hline Peak & Retention time & Compounds & $\begin{array}{l}\text { Relative } \\
(\%)\end{array}$ & Area & Calculated RI & $\begin{array}{l}\text { Identification } \\
\text { methods }\end{array}$ \\
\hline 1 & 11.258 & Decanal & 2.62 & & 1205 & $a, b, c$ \\
\hline 2 & 25.464 & $\alpha$-Curcumene & 4.49 & & 1478 & $a, b, c$ \\
\hline 3 & 26.177 & $\alpha$-Zingiberene & 14.92 & & 1490 & $a, b, c$ \\
\hline 4 & 26.898 & $\beta$-Bisabolene & 2.76 & & 1502 & $a, b, c$ \\
\hline 5 & 26.981 & $\alpha$-Farnesene & 3.27 & & 1504 & $a, b, c$ \\
\hline 6 & 27.695 & $\beta$-Sesquiphellandrene- & 6.16 & & 1518 & $a, b, c$ \\
\hline 7 & 34.398 & Zingerone & 47.65 & & 1641 & $a, b, c$ \\
\hline 8 & 48.779 & Methylhexadecanoate & 4.42 & & 1922 & $a, b, c$ \\
\hline 9 & 56.185 & Methyl 10-trans,12-cis-octadecadienoate & 1.88 & & 2090 & $a, b, c$ \\
\hline 10 & 56.405 & 10-Octadecenoic acid, methyl ester & 1.16 & & 2095 & $a, b, c$ \\
\hline 11 & 59.531 & Gingerol & 4.37 & & 2237 & $a, b, c$ \\
\hline 14 & 63.227 & Ethyl iso-allocholate & 2.28 & & 2521 & $a, b, c$ \\
\hline 16 & 64.610 & n.i & 0.82 & & & \\
\hline \multirow[t]{2}{*}{17} & 68.361 & n.i & 0.64 & & & \\
\hline & & Total identified & 97.45 & & & \\
\hline
\end{tabular}

${ }^{a}$ Compounds listed according to the HP-5MS elution order; ${ }^{b}$ retention index (RI) calculate dosing $\mathrm{C}_{7}$ to $\mathrm{C}_{40} n$-alkanes in capillary column (HP-5MS); ${ }^{\mathrm{C}}$ Identification based on the comparison of mass spectra of NIST libraries; Relative Area (\%): Percentage of the area (\%) that the compound occupies within the chromatogram; RI: Retention Index; n.i: not identified.

Table 4. Minimal inhibitory concentration (MIC) and minimum bactericidal concentration (MBC) of the Zingiber officinale Roscoe, the leaf aqueous extract against the Staphylococcus spp. negative coagulase isolated from six nasal swabs from veterinary students at the University of Paraná (UNIPAR), Paraná, Brazil, 2018.

\begin{tabular}{|c|c|c|}
\hline \multicolumn{3}{|c|}{ Inhibitory Concentration - Leaves } \\
\hline \multirow[t]{2}{*}{ Bacterial Samples } & \multicolumn{2}{|l|}{ Leaves } \\
\hline & MIC & $\mathrm{MBC}$ \\
\hline 01 & $250 \mathrm{mg} / \mathrm{mL}$ & $>250 \mathrm{mg} / \mathrm{mL}$ \\
\hline 02 & $250 \mathrm{mg} / \mathrm{mL}$ & $>250 \mathrm{mg} / \mathrm{mL}$ \\
\hline 03 & $250 \mathrm{mg} / \mathrm{mL}$ & $>250 \mathrm{mg} / \mathrm{mL}$ \\
\hline 04 & $250 \mathrm{mg} / \mathrm{mL}$ & $>250 \mathrm{mg} / \mathrm{mL}$ \\
\hline 05 & $125 \mathrm{mg} / \mathrm{mL}$ & $>250 \mathrm{mg} / \mathrm{mL}$ \\
\hline 06 & $250 \mathrm{mg} / \mathrm{mL}$ & $>250 \mathrm{mg} / \mathrm{mL}$ \\
\hline
\end{tabular}

Legend: MIC - Minimum Inhibitory Concentration, MBC - Minimum Bactericidal Concentration. 
Table 5. Minimal inhibitory concentration (MIC) and minimum bactericidal concentration (MBC) of the Zingiber officinale Roscoe the rhizome aqueous extract against the Staphylococcus spp. negative coagulase isolated from six nasal swabs from veterinary students at the University of Paraná (UNIPAR), Paraná, Brazil, 2018.

\begin{tabular}{|c|c|c|}
\hline \multirow[t]{2}{*}{ Bacterial Samples } & \multicolumn{2}{|c|}{ Rhizomes } \\
\hline & MIC & $\mathrm{MBC}$ \\
\hline 02 & $7.81 \mathrm{mg} / \mathrm{mL}$ & $7.81 \mathrm{mg} / \mathrm{mL}$ \\
\hline 03 & $7.81 \mathrm{mg} / \mathrm{mL}$ & $15.62 \mathrm{mg} / \mathrm{mL}$ \\
\hline 06 & $15.62 \mathrm{mg} / \mathrm{mL}$ & $31.25 \mathrm{mg} / \mathrm{mL}$ \\
\hline
\end{tabular}

Legend: MIC - Minimum Inhibitory Concentration, MBC - Minimum Bactericidal Concentration

Table 6. Classification according to the fractional inhibitory concentration index (FICI) for the combinations between the drugs and $1 / 2$ MIC of the Zingiber officinale Roscoe the rhizome aqueous extract against the Staphylococcus spp. negative coagulase isolated from six nasal swabs from veterinary students at the University of Paraná (UNIPAR), Paraná, Brazil, 2018.

\begin{tabular}{|c|c|c|c|}
\hline \multicolumn{4}{|c|}{$\mathrm{FICl}-1 / 2 \mathrm{MIC}$} \\
\hline Bacterial Samples & AMP & OXA & VAN \\
\hline 1 & Synergistic & Synergistic & Additive \\
\hline 2 & Additive & Additive & Indifferent \\
\hline 3 & Additive & Additive & Additive \\
\hline 4 & Indifferent & Antagonist & Antagonist \\
\hline 5 & Indifferent & Indifferent & Indifferent \\
\hline 6 & Synergistic & Indifferent & Additive \\
\hline
\end{tabular}

Legend: AMP - Ampicillin, OXA - Oxacillin, VAN - Vancomycin

Table 7. Classification according to the fractional inhibitory concentration index (FICl) for the combinations between the drugs and $1 / 4 \mathrm{MIC}$ of the Zingiber officinale Roscoe rhizome aqueous extract against the Staphylococcus spp. negative coagulase isolated from six nasal swabs from veterinary students at the University of Paraná (UNIPAR), Paraná, Brazil, 2018.

\begin{tabular}{|l|l|l|l|}
\hline Bacterial Sample & AMP & OXA & VAN \\
\hline 1 & Indifferent & Additive & Indifferent \\
\hline 2 & Additive & Additive & Indifferent \\
\hline 3 & Synergistic & Additive & Additive \\
\hline 4 & Additive & Antagonist & Antagonist \\
\hline 5 & Indifferent & Indifferent & Indifferent \\
\hline 6 & Synergistic & Additive & Indifferent \\
\hline
\end{tabular}

pharmaceutical drugs (plant origin), especially due to the constant emergence of microorganisms resistant to conventional antimicrobials (Silva and Fernandes-Júnior, 2010).

According to the study of Jardim et al. (2019), the results showed that the aqueous extracts of the leaves presented high levels of these compounds $(160.86 \pm 0.17 \mu \mathrm{g}$ eq. AG $/ \mathrm{mg}$ extract), statistically different $(p<0.05)$ from the aqueous extract of the rhizomes $(132.018 \pm 3.31 \mu \mathrm{g}$ eq. $\mathrm{AG} / \mathrm{mg}$ extract). Several studies indicate that antioxidant activity is directly related to the content of total phenolic compounds, which act mainly on free radical sequestration (Beal, 2006; Sahoo et al., 2014).

The antioxidant capacity of $Z$. officinale rhizomes is known to be attributed especially by the presence of phenolic compounds that are chemical structures that have hydroxyls and aromatic rings, in single or polymer forms (Angelo and Jorge, 2007). Its antioxidant capacity is due to the presence of hydroxyls in its molecules that eliminate free radicals by the formation of phenoxyl (Gupta and Sharma, 2014).

The extracts tested showed inhibitory activity against the Staphylococcus spp., with the aqueous extract of the rhizome standing out. The aqueous extract of the leaves also showed good results as an antibacterial, but only in higher concentrations. In this work, the higher potential of the rhizome extract relative to that of the leaf extract may be a consequence of its phytochemical compositions since the leaves do not have as many bioactive compounds as the rhizome. Besides flavonoids, tannins, and saponins that are also present in the leaves, the rhizome also has alkaloids and glycosides that confer on them greater antioxidant and antimicrobial capacities, among others (Jardim et al., 2019; Saad et al., 2014).

Research using ginger to verify its antimicrobial activity and synergistic potential has previously been carried out (Baljeet et al., 2015; Betoni et al., 2006); however, studies using the E-test approach as a way of verification is scarce in the literature. The present work sought some specificity to clarify this potential since the E-test is a safe alternative to other tests, such as broth microdilution (Manfredini et al., 2011) and has the advantage of being easy to use and interpret, besides allowing tests involving microorganisms that are difficult to manipulate (ANVISA, 2008).

Betoni et al. (2006) tested the synergism of the ginger extract by Kirby and Bauer's disc diffusion method, concluding that there was synergism with only two drugs, netilmicin, and tetracycline. This result is in line with the results of the present study, in which synergism with ampicillin was observed at the two concentrations tested. In this work, the choice of the E-test strips to find the new MIC 
of the ginger rhizome extract combined with the selected drugs is due to the fact that this is an easily interpreted method and that produces accurate MIC results, thus showing a more reliable result.

Shahrajabian et al. (2019) has reported that ginger, among other spices, has been used in traditional Chinese medicine for nearly 200 years for its anti-inflammatory, antimicrobial, antipyretic, antioxidant, and analgesic properties, among others. The authors have also pointed out the great commercial potential of this medicinal plant's extract, either as a dietary supplement or in the pharmaceutical industry.

Considering the potential of the aqueous extracts of Zingiber officinale Roscoe found in this study either as auxiliary agents to synthetic drugs already in the market or as single products, the therapeutic use of this plant cannot be ignored, especially considering the effectiveness of the low concentration used against the multiresistant samples.

\section{Materials and methods}

\section{Origin and number of samples}

The bacterial collection was carried out in the municipality of Umuarama, located at latitude 2345'59 "south and longitude 5319'30" west, northwestern region of Paraná state, Brazil. Nasal swab samples were collected from six dog tutors, who were students of the Veterinary Medicine course at the University of Paraná (UNIPAR).

This research was approved by the Research Ethics Committee Involving Human Beings (CEPEH) under number CAAE 71715417.5.0000.0109.

Along with the isolates, a standard strain of Staphylococcus aureus from the American Type Culture Collection (ATCC25923) was used.

For the collection of the nasal swab samples of dog's owners, it was first moistened in the transport medium itself. This moistened swab was introduced into the tutor's nasal orifice, compressing it with rotational movements, then introduced into the transport medium for further processing at the Preventive Veterinary Medicine and Public Health Laboratory of the Animal Science Graduate Program with Emphasis Bioactive Products.

\section{Culture and isolation}

Each swab was inserted into Brain Heart Infusion (BHI), and incubated at $37^{\circ} \mathrm{C}$ for 24 hours, then seeded in Mannitol Salt Agar medium and incubated at $370 \mathrm{C}$ for up to 48 hours for isolation of gram-positive bacteria. Each colony was subjected to analysis of macroscopic, microscopic, and biochemical characteristics, allowing the identification of these microorganisms as Staphylococcus spp. negative coagulase (Quinn et al., 1994; Winn et al., 2008). In isolation, a standard strain of Staphylococcus aureus from the American Type Culture Collection (ATCC 25923) was used.

\section{Disk Diffusion Test}

The antimicrobial susceptibility testing on the nasal swab samples was performed according to the Clinical and Laboratory Standards Institute (CLSI, 2018). The disk diffusion test was performed after standardization of the inoculums in brain heart infusion (BHI) broth according to the $0.5 \mathrm{McF}$ arland scale using antimicrobial discs. The results were recorded according to the CLSI (2018) guidelines for bacteria isolated from humans and the size of the inhibition halos (in millimeters). The antimicrobials evaluated were ampicillin $(10 \mu \mathrm{g})$, cephalothin $(30 \mu \mathrm{g})$, cefotaxime $(30 \mu \mathrm{g})$, clindamycin $(2 \mu \mathrm{g})$, enrofloxacin $(5 \mu \mathrm{g})$, erythromycin (15 $\mu \mathrm{g})$, gentamicin $(10 \mu \mathrm{g})$, oxacillin $(1 \mu \mathrm{g})$, penicillin $(10 \mathrm{U})$, tetracycline $(30 \mu \mathrm{g})$, and vancomycin $(30 \mu \mathrm{g})$.

\section{Preparation of the Extract \\ Biological Material}

The species Zingiber officinale Roscoe (rhizomes and leaves) was cultivated in the experimental beds of the Medicinal Garden of Campus II of the UNIPAR, Umuarama (2345'44.9" S and 5316'17.5" W), and the soil has the Caiuá sandstone formation, which belongs to class LVd19 (Merlin et al., 2016) and is deposited in the Herbarium of the Medicinal Garden of UNIPAR campus, under number 163. Afterward, the rhizomes and leaves were collected in the morning period in April 2017 and dehydrated in a forced circulation oven at 35 ${ }^{\circ} \mathrm{C}$ for 20 days.

\section{Extraction of bioactive compounds - raw extract}

The powdered samples of rhizomes and leaves were subjected to aqueous extraction according to Otunola et al. (2014) and Jardim et al. (2019). Briefly, $40 \mathrm{~g}$ of each powder sample was mixed with $800 \mathrm{~mL}(5 \%, \mathrm{p} / \mathrm{v})$ of boiling distilled water $\left(95-100^{\circ} \mathrm{C}\right)$ by stirring for $10 \mathrm{~min}$. The filtrates were lyophilized with a Lyophilizer VirTis K (VirTis, Gardiner, New York, USA) for $48 \mathrm{~h}$. The lyophilizates of each sample was stored at $-20{ }^{\circ} \mathrm{C}$ in an airtight glass vial protected from light for further analysis.

\section{Extract analysis by gas chromatography and mass spectroscopy}

The chemical identification of the essential oil was performed by GC-MS (Agilent 7890B - 5977A MSD). The capillary column was HP-5MS IU 5\% (30 m x $0.25 \mathrm{~mm} \times 0.25$ $\mu \mathrm{m})$, with an initial temperature of $40{ }^{\circ} \mathrm{C}$ for 2 minutes, followed by heating of $5^{\circ} \mathrm{C} / \mathrm{min}$ until reaching a temperature of $250{ }^{\circ} \mathrm{C}$ remaining for $10 \mathrm{~min}$ and ending with heating from $40{ }^{\circ} \mathrm{C} / \mathrm{min}$ to $300{ }^{\circ} \mathrm{C}$ remaining for $1 \mathrm{~min}$. Helium was used as carrier gas at a linear velocity of $1 \mathrm{~mL} \mathrm{~min} \mathrm{mp}^{-1}$ up to $300^{\circ} \mathrm{C}$ and a pressure release of $8.23 \mathrm{psi}$. The injector temperature was $280^{\circ} \mathrm{C}$; the injection volume was $1 \mu \mathrm{L}$; the injection occurred in Split mode (2: 1). The transfer line was maintained at 280 ${ }^{\circ} \mathrm{C}$, the ionization source, and quadrupole at $230{ }^{\circ} \mathrm{C}$ and 150 ${ }^{\circ} \mathrm{C}$, respectively. The $\mathrm{EM}$ detection system was used in "scan" mode, at a mass/charge rate $(\mathrm{m} / \mathrm{z})$ of $40-600$, with a "solvent delay" of $3 \mathrm{~min}$. The compounds were identified by comparing the mass spectra found in NIST 11.0 libraries and by comparing the retention indices (RI) obtained by a homologous series of standard (C7-C28) (Adams, 2012).

\section{Evaluation of the antibacterial activity of the extract}

The antibacterial activities of the Zingiber officinale Roscoe plant extracts were evaluated by the Broth Microdilution method on a 96-well U-bottom microplate layout with the lid used to identify the plant parts to which the extracts corresponded (rhizomes or leaves) (CLSI, 2018).

A bacterial suspension of the isolates was prepared using the 0.5 McFarland scale with the BHI medium. Then, a dilution was performed to obtain a final concentration of $10^{6}$ $\mathrm{CFU} / \mathrm{mL}$. Subsequently, a stock solution containing 500 $\mathrm{mg} / \mathrm{mL}$ of the extract (leaves and rhizomes) in a Mueller Hinton Broth medium was prepared to obtain serial dilutions ranging from $1.95 \mathrm{mg} / \mathrm{mL}$ to $250 \mathrm{mg} / \mathrm{mL}$. The control assays of the culture medium, extract, and bacterial inoculum were included in the 96-well microplate. After the dilution on the plate, $5 \mu \mathrm{L}$ of the standardized bacterial suspension was 
added into each well, and the plates were subsequently incubated at $37^{\circ} \mathrm{C}$ for $24 \mathrm{~h}$. After the incubation period, the growth was evidenced by the appearance of pink color in the wells upon the addition of $10 \mu \mathrm{L}$ of 2,3,5Triphenyltetrazolium chloride indicator at $10 \%$. The MIC, defined as the lowest concentration that inhibits the bacterial growth, and $\mathrm{MIC}_{90 \%}$ of each extract was calculated. A loopful of the culture was collected from each well that had no bacterial growth and inoculated onto a MuellerHinton Agar (MHA) plate. The plates were incubated at $37^{\circ} \mathrm{C}$ for $24 \mathrm{~h}$, after which the $\mathrm{MBC}$, defined as the lowest concentration that kills the inoculum, was assessed. All the assays were performed in triplicate.

\section{Verification of the synergism between the aqueous extract} of $Z$. officinale rhizome and conventional antimicrobials

Synergism was observed against the six isolates of Staphylococcus spp. in vitro by the disk diffusion test (CLSI, 2018) using E-test ${ }^{\circledast}$ strips (bioMérieux, Marcy-l'Étoile, France). Susceptibility tests were performed for each isolate on the control MHA plates alongside experimental MHA plates containing the diluted ginger extract in MHA (\% v/v) to obtain the $1 / 2 \mathrm{MIC}$ and $1 / 4 \mathrm{MIC}$ according to the values previously obtained in the broth microdilution assays (Mahon and Manuselis, 1995). Synergism of the ginger extract with the following three drugs was evaluated: ampicillin (AMP), to which all the isolates showed resistance in the disc diffusion assay; oxacillin (OXA) and vancomycin (VAN), because of their relevance for the treatment of staphylococcus infections. The rhizome extract was used because it exhibited the highest antibacterial activity at the previous stage. The MIC values of the E-test method $(\mu \mathrm{g} / \mathrm{mL})$ were recorded by observing the elliptic inhibitory areas after incubation at $37^{\circ} \mathrm{C}$ for $24 \mathrm{~h}$, and the results were obtained by comparing the values of the control and experimental samples (Zago et al., 2009).

The combined actions of the antimicrobials with the ginger rhizome extract were classified by calculating the fractional inhibitory concentration index (FICl) through the following formula: $F I C_{A}+F I C_{B}$.

$F I C_{A}$ is the $M I C_{A}$ of the drug and extracts combination divided by the $M I C_{A}$ of the extract alone, and $F I C_{B}$ is the $M I C_{B}$ of the drug and extract combination divided by the $M I C_{B}$ of the extract alone. The results were then separated into four groups: synergistic $(\mathrm{FICl}<0.5)$, additive $(0.5 \leq \mathrm{FICl} \leq 1)$, indifferent $(1<\mathrm{FICl} \leq 4)$, and antagonist $(\mathrm{FICl}>4)$, the additive being the mixture with the result equal to the sum of the results alone, and the synergistic the mixture where the result is greater than the sum of the results alone (Gutierrez et al., 2009).

\section{Conclusion}

This study shows the use of aqueous ginger extract (Zingiber officinale Roscoe) from the rhizomes as an antimicrobial or auxiliary agent to antimicrobials, as well as a good therapeutic alternative for the treatment of Staphylococcus spp., even for multiresistant ones, revealing the need for further studies on the mechanisms of action of bioactive compounds and viability of extracts of this species Zingiber officinale Roscoe. Both parts of the Zingiber officinale Roscoe plant (rhizome and leaves) showed evidence as an alternative therapy for antibacterial control. The aqueous extracts of Zingiber officinale Roscoe, under the conditions of this study, showed high antioxidant activity by DPPH (free radical 1,1 diphenyl 2 picrylhydrazyl) and FRAP (Ferric Reducing Antioxidant Power) techniques. The results of this research demonstrated the bacteriostatic effect of aqueous extracts of Zingiber officinale Roscoe rhizomes and leaves against $E$. coli isolates from human feces samples.To understand the effectiveness of aqueous extracts of Zingiber officinale Roscoe (rhizomes and leaves) in their role in modulating biological and molecular pathways, thus enabling new therapeutic strategies, more detailed research in vitro and in vivo will be necessary.

\section{Authors: All research was carried out by the authors \\ Financial support: yes \\ Conflict of interest: none}

\section{Acknowledgments}

We are thankful to UNIPAR, CAPES, CNPq (CP 12/2017), and the Araucária Foundation (CP 09/2016 Institutional Program for Basic and Applied Research - Protocol: 47661.491.48325.12122016) for funding this research.

\section{REFERENCES}

Suhad A (2012) Study the Antibacterial Activity of Zingiber officinale rhizome against some of pathogenic bacteria. AlMustansiriya J Sci, 23:63-70.

Adams RP (2012) Identification of essential oils components by gas chromatography/mass spectroscopy, 4th edn. Allured Bussiness Media, USA.

Angelo PM, Jorge N (2007) Compostos fenólicos em alimentos - Uma breve revisão. R Inst Adolfo Lutz. 66: 1-9.

ANVISA - Agência Nacional de Vigilância Sanitária (2004) Universidade Federal do estado de São Paulo - UNIFESP. Curso de Infecção Relacionada à Assistência à Saúde - IrAs. ANVISA - Agência Nacional de Vigilância Sanitária (2008) Módulo 5: Teste de sensibilidade a antimicrobianos. http://www.anvisa.gov.br/servicosaude/controle/rede rm Lcursos/boas praticas/modulo5/objetivos.htm (accessed 26 July 2019).

Argudín MA, Vanderhaeghen W, Vandendriessche $S$, Vandecandelaere I, André FX, Denis O, Coenye T, Butaye P (2015) Antimicrobial resistance and population structure of Staphylococcus epidermidis recovered from animals and humans. Vet Microbiol. 178: 105-113.

Azizi A, Aghayan S, Zaker S, Shakeri M, Entezari N, Lawaf S (2015) In vitro effect of zingiber officinale extract on growth of Streptococcus mutans and Streptococcus sanguinis. Int J Dent. 2015.

Baljeet SY, Simmy G, Ritika Y, Roshanlal Y (2015) Antimicrobial activity of individual and combined extracts of selected spices against some pathogenic and food spoilage microorganisms. Int Food Res J. 22: 2594-2600.

Beal BH (2006) Atividade antioxidante e identificação dos ácidos fenólicos do gengibre (Zingiber officinale roscoe). Master's degree dissertation. Universidade Federal de Santa Catarina, Florianópolis, Santa Catarina, Brasil.

Becker K, Heilmann C, Peters G (2014). Coagulase-negative staphylococci. Clin Microbiol Rev. 27(4): 870-926.

Betoni JEC, Mantovani RP, Barbosa LN, Di Stas LCi, Fernandes Junior A (2006) Synergism between plant extract and antimicrobial drugs used on Staphylococcus aureus diseases. Mem Inst Oswaldo Cruz. 101: 387-390.

Chan EWC, Wong SK (2015) Phytochemistry and pharmacology of ornamental gingers, Hedychium 
coronarium and Alpinia purpurata: a review. J Integr Med. 13: 368-379.

Chan WE, Lim YY, Wong SK (2011) Antioxidant properties of ginger leaves: An overview. Free Radic Res. 1: 6-16.

Chand B (2019) Antibacterial effect of garlic (Allium sativum) and ginger (Zingiber officinale) against Staphylococcus aureus, Salmonella typhi, Escherichia coli and Bacillus cereus. J Microbiol Biotechnol Food Sci. 2019: 2481-2491.

CLSI - Clinical and Laboratory Standards Institute (2018) Performance Standards for Antimicrobial Susceptibility Testing: 28th Informational Supplement. Clinical and Laboratory Standards Institute, Wayne, PA.

Coelho SDM, Moraes RAM, Soares LDC, Pereira IA, Gomes LP, Souza MMS (2007) Resistance pattern and detection of mecA gene in oxacillin-resistant isolates of Staphylococcus aureus and Staphylococcus intermedius from animal and human samples. Cienc Rural. 37: 195-200.

Gutierrez J, Barry-Ryan C, Bourke P (2009) Antimicrobial activity of plant essential oils using food model media: efficacy, synergistic potential, and interactions with food components. Food Microbiol. 26: 142-150.

Hasenclever L, Paranhos J, Costa CR, Cunha G, Vieira D. (2017). A indústria de fitoterápicos brasileira: desafios e oportunidades. Cien Saude Colet. 22(8): 2559-2569.

Jardim MFA, Furlan LCO, dos Santos IC, Barbosa LN, Otutumi LK, Jacomassi E, Germano RM, Soares AA (2019) Antibacterial and antioxidant activity of water extracts of Zingiber officinale roscoe leaves and rhizomas cultivated in unipar's medical court. Braz. J. Dev. 5: 18292-18309.

Kuroda T, Kinoshita Y, Niwa H, Shinzaki Y, Tamura N, Hobo S, Kuwano SA (2016) Meticillin-resistant Staphylococcus aureus colonisation and infection in Thoroughbred racehorses and veterinarians in Japan. Vet Rec. 178:473.

Lozano C, Rezusta A, Ferrer I, Pérez-Laguna V, Zarazaga M, Ruiz-Ripa L, Revillo MJ, Torres C (2017) Staphylococcus pseudintermedius human infection cases in Spain: dog-tohuman transmission. Vector Borne Zoonotic Dis. 17: 268270.

Mahon CR, Manuselis JRG (1995) Textbook of Diagnostic Microbiology. WB Saunders Philadelphia.

Manfredini C, Picoli SU, Becker AP (2011) Comparação de métodos na determinação de sensibilidade à vancomicina em Staphylococcus aureus resistente à meticilina. J Bras Patol Med Lab. 47: 141-145.

Menegotto FR, Picoli SU (2007) Staphylococcus aureus oxacilina resistente (MRSA): incidência de cepas adquiridas na comunidade (CA-MRSA) e importância da pesquisa e descolonização em hospital. Rev Bras Anal Clin. 39: 147150.

Merlin E, Melato E, Cagnini CZ, Reinisz IC, Bonacina C, Novello PM (2016) O. Alberton, Avaliação Da Micorrização E Atividade Microbiana De Um Solo Cultivado Com Plantas Fitoterápicas. J Agric Sci. 5: 190-198.

Moraes AL, Araújo NGP, Braga TDL (2016) Automedicação: revisando a literatura sobre a resistência bacteriana aos antibióticos. R El Estácio Saúde. 5: 122-132.

Otunola GA, Oloyede OB, Oladiji AT, Afolayan AJ (2014) Selected spices and their combination modulate hypercholestererolemia-induced oxidative stress in experimental rats. Biol Res. 47: 1-6.

Quinn PJ, Carter ME, Markey B, Carter GR (1994). Clinical Veterinary Microbiology. Wolfe Publishing.

Rajapaksha P, Elbourne A, Gangadoo S, Brown R, Cozzolino D, Chapman J (2019) A review of methods for the detection of pathogenic microorganisms. Analyst. 144(2): 396-411.

Saad R, Wai L, Hanif N, Yusuf E, Asmani F (2014) Comparative studies of Zingiber officinale leaves and rhizomes on the antibacterial effect. Int J Chem Pharm Sci. 3: 249-261.

Saber H, Jasni AS, Jamaluddin TZMT, Ibrahim R. (2017) A review of Staphylococcal cassette chromosome mec (SCCmec) types in coagulase-negative staphylococci (CoNS) species. Malays J Med Sci. 24(5): 7.

Sahoo S, Singhi S, Nayak S (2014) Chemical composition, antioxidant and antimicrobial activity of essential oil and extract of Alpinia malaccensis Roscoe (Zingiberaceae). Int J Pharm Pharm. 6: 183-188.

Sebiomo A, Awofodu AD, Awosanya AO, Awotona FE, Ajayi AJ (2011) Comparative studies of antibacterial effect of some antibiotics and ginger (Zingiber officinale) on two pathogenic bacteria. J Microbiol Antimicrob. 3: 18-22.

Shahrajabian MH, Sun W, Cheng Q (2019) Clinical aspects and health benefits of ginger (Zingiber officinale) in both traditional Chinese medicine and modern industry. Acta Agr Scand. 69: 546-556.

Silva NCC, Fernandes-Júnior A (2010) Biological properties of medicinal plants: a riview of their antimicobial activity. J Venom Anim Toxins Incl Trop Dis. 16: 402-413.

Singer AC, Shaw H, Rhodes V, Hart A (2016) Review of antimicrobial resistance in the environment and its relevance to environmental regulators. Front Microbial. 7: 1728.

Soares AA, Jacomassi E, da Mata R, Lopes KFC, Borges JL, Pereira UP, Germano RM, Otutumi LK, Martins LA, Gonçalves DD (2018) Antimicrobial activity of species Zingiber officinale Roscoe and Alpinia purpurata (Vieill.) K. Schum.(Zingiberaceae). Semina: Ciênc Agrár. 39: 18491861.

Tavares W (2000) Bactérias gram-positivas problemas: resistência do estafilococo, do enterococo e do pneumococo aos antimicrobianos. Rev Soc Bras Med Trop. 33: 281-301.

Van Duijkeren E, Kamphuis M, Van der Mije IC, Laarhoven LM, Duim B, Wagenaar JA, Houwers DJ (2011) Transmission of methicillin-resistant Staphylococcus pseudintermedius between infected dogs and cats and contact pets, humans and the environment in households and veterinary clinics. Vet microbiol. 150: 338-343.

Voravuthikunchai SP (2007) Family Zingiberaceae compounds as functional antimicrobials, antioxidants, and antiradicals. Food. 1: 227-240.

WHO - World Health Organization (2018) OMS lança estratégia para combater resistência de bactérias a antibióticos. https://nacoesunidas.org/oms-lancaestrategia-para-combater-resistencia-de-bacterias-aantibioticos/, 2018. (accessed 5 august 2019).

Winn WC, Allen SD, Janda WM, Koneman EW, Procop GW, Schreckenberger PC, Woods GL (2008) Diagnóstico Microbiológico: texto e atlas colorido, sixth ed., Guanabara Koogan, Rio de Janeiro.

Zago JA, Ushimaru PI, Barbosa LN, Fernandes Junior A (2009) Sinergismo entre óleos essenciais e drogas antimicrobianas sobre linhagens de Staphylococcus aureus e Escherichia coli isoladas de casos clínicos humanos. Rev Bras Farmacogn. 19: 828-833. 